INDEPENDENT JOURNAL OF MANAGEMENT \& PRODUCTION (IJM\&P)

\title{
IMPACT OF SMARTPHONE ADDICTION ON ACADEMIC PERFORMANCE OF BUSINESS STUDENTS: A CASE STUDY
}

Md. Shamsul Arefin

School of Business, Uttara University, Bangladesh

Email: arreefin@gmail.com

Md. Rafiqul Islam

School of Business, Uttara University, Bangladesh

Email: rafiq.mgt2009@gmail.com

Mohitul Ameen Ahmed Mustafi School of Business, Uttara University, Bangladesh

Email: mustafi@uttarauniversity.edu.bd

Sharmina Afrin School of Business, Uttara University, Bangladesh

Email: sharmina1970@gmail.com

Nazrul Islam School of Business, Uttara University, Bangladesh Email: nazrulku@gmail.com

Submission: 08/02/2017

Revision: 24/02/2017

Accept: 06/03/2017

\section{ABSTRACT}

The development of telecom technology has a profound impact on the academic lives of the students. Smartphone usage became popular to young generation because of its educational and entertaining options by using the numerous applications. Among the young people, students are increasingly using Smartphone. But excessive Smartphone usage usually makes the students addicted to it and that impacts on user's academic performance, daily activities, physical and mental health, withdrawal tendency, and social relationships. This study aims at identifying the factors that affect the level of Smartphone addiction to the students and its impact on their overall academic performance. 
INDEPENDENT JOURNAL OF MANAGEMENT \& PRODUCTION (IJM\&P)

http://www.ijmp.jor.br

v. 8, n. 3, July - September 2017

ISSN: 2236-269X

DOI: 10.14807/ijmp.v8i3.629

A structured questionnaire has been developed to gather data from the students. A total of 247 questionnaires were collected from the business students of a private university of Bangladesh. Using Structural Equation Modeling (SEM), data were analyzed. Results revealed five Smartphone addiction factors such as, positive anticipation, impatience, withdrawal, daily-life disturbance, and cyber friendship. Factors like increased impatience and daily-life disturbance were found significantly related to the academic performance of the business students of Bangladesh. This study suggests that the students should reduce the intense use of Smartphone for smoothly doing their daily-life activities.

Keywords: Smartphone Addiction, Structural Equation Modeling, Increased Impatience, Daily-life Disturbance, Cyber Friendship.

\section{INTRODUCTION}

Smartphone has become one the important devices used to simplify human lives and their activities. The usage of smartphone has been increased in recent years in Bangladesh. The number of Smartphone users in Bangladesh has increased by 8.20 million in 2015 and the figure will be more than doubled by 2021 (BTRC, 2016). In each year, more than 6.00 million new users are added to existing smartphone users (ERICSSON MOBILITY REPORT, 2015).

Smartphone combines both computer and mobile phone features into one device having web browsers that can be connected through mobile internet, and WiFi internet network. It is a source of education and entertainment through the usage of numerous applications. Smartphone has become more popular to all generations because of its social networking applications such as Twitter, Facebook that connects people under one umbrella.

Smartphone users habitually engage in browsing web, checking e-mail, pocking social networking sites, sending text messages with touch and giant screen facility. However, the excessive usage of smartphone causes adverse effect on users who gradually become addicted to it. It has been observed that smartphone addiction is more severe than the addiction to mobile phones, computers, and even internet.

Smartphones are generally used by young students, who study in college and university. Students seem to be vulnerable to technology overuse because of their 
INDEPENDENT JOURNAL OF MANAGEMENT \& PRODUCTION (IJM\&P)

http://www.ijmp.jor.br

v. 8, n. 3, July - September 2017

ISSN: 2236-269X

DOI: 10.14807/ijmp.v8i3.629

developmental dynamics, freedom, and lack of responsibility on society and family (KANDELL, 1998).

As addiction is exhibited in many forms, the internet addiction is one of the addictions, that has some common features. This study considers internet addiction to identify the smartphone addiction criteria. Beyond the similarities between internet and smartphone, the later has some salient features which are absent in preceding one.

For example, the portability feature of smartphone gives its users comfort and connects people with whom they interact. Furthermore, users can shape their smartphones more personal by using various apps that are distinct from others. Thus, internet addiction is quite distinct from smartphone addiction of the users.

While using smartphone, people become unmindful that cause thousands of death and faulty activities. Its adverse effect is also seen in work-related tasks, classroom leanings (HISCOCK, 2004; SELWYN, 2003), and academic performance (KUSS; GRIFFTHS, 2011). In classroom, students engage in surfing web, social networking, checking emails and text messages and consequently pay less attention to their lessons (HISCOCK, 2004; SELWYN, 2003). Moreover, students spend more time with their smartphone that hampers their regular studies.

It is necessary to identify the criteria of smartphone addiction that is embedded with the features of smartphone. Hence, this study aims to identify the smartphone addiction factors specifying the characteristics of smartphone. Furthermore, the perception of undergraduate students on smartphone addiction was investigated and the possible impact of this addiction on their academic performance was evaluated.

The awareness of possible negative consequences of smartphone usage certainly reduces the overuse of smartphone. Few studies have been articulated the impact of smartphone addiction on students' academic performance (e.g., SAMAHA; HAWI, 2016; HAWI; SAMAHA, 2016), stress (CHIU, 2014) and life satisfaction (SAMAHA; HAWI, 2016). Therefore, this study attempts to explore the impact of smartphone addiction on students' academic performance in tertiary level of Bangladesh.

\section{Background of the Study}


INDEPENDENT JOURNAL OF MANAGEMENT \& PRODUCTION (IJM\&P)

http://www.ijmp.jor.br

V. 8, n. 3, July - September 2017

ISSN: 2236-269X

DOI: 10.14807/ijmp.v8i3.629

Glanze, Anderson, and Anderson (1998, p. 321) defined addiction as "compulsive, uncontrollable dependence on a substance, habit, or practice to such a degree that cessation causes a severe emotional, mental, or physiological reaction." Researcher argued differently on applications of addiction concept. Some researcher emphasized on the application of addiction concept in chemical substances, such as alcohol or drug (BRATTER; FORREST, 1985; WALKER, 1989; RACHLIN, 1990). On the other hand, some researchers used this concept in problematic behaviors, such as internet addiction (YOUNG, 1998; KANDELL, 1998; GRIFFITHS, 1998; GOLDBERG, 1995), computer game playing (GRIFFITHS; HUNT, 1995), sex (CARNES, 1983), and pathological gambling (GRIFFITHS, 1990).

Addiction is represented in different forms. Peele (1985) termed addiction as compulsive or overused activity. Akers (1991) relates addiction to psychological demand of a drag, which is represented through impatience, withdrawal, and dependence. Here, the psychological demand is explained by the habitual behavior represented an addicted person.

The addicted person intends to get relief of pain, anxiety, and other behavioral demands such as increased power, comfort, control, and self-esteem (PEELE, 1985). Addictive behavior is assumed to enhance mood and emotional stability when people intended to adjust themselves to different situation.

Technology addiction is becoming prevalent everywhere with various forms such as Internet addiction, mobile addiction and smartphone addiction. Young (1998) reported internet addiction having online dependency symptoms such as withdrawal, impatience, loss of control, disorder in academic, job, and social performance.

Based on Internet Related Addictive Behavior Inventory, Brenner (1997) reported some daily-life disturbances such as less sleeping time, less time management, missing meal and other symptoms. Accordingly, Ko et al., (2006) identified several factors of internet addiction, such as impatience, withdrawal, compulsive use, and interpersonal problem.

In recent years, the extant research has been shifted from internet addition to mobile phone addiction. Researcher of mobile phone addiction uses internet addiction measures in designing mobile phone addiction instrument. Underpinning Young and Goldberg's Internet Addiction tool, most researchers 
INDEPENDENT JOURNAL OF MANAGEMENT \& PRODUCTION (IJM\&P)

http://www.ijmp.jor.br

V. 8, n. 3, July - September 2017

ISSN: 2236-269X

DOI: 10.14807/ijmp.v8i3.629

developed mobile addiction tool emphasizing withdrawal, impatience, dependency, and self-control. In a study on adolescents, Koo (2009) identified key important factors of mobile addiction, such as impatience, withdrawal, daily life disturbances, and compulsive-impulsive control.

Previous mobile phone research focused on addictive symptoms as the frequency of usage for calling and text messaging (OZCAN; KOCAK, 2003; WALSH; WHITE, 2006, 2007), mobile phone involvement (WALSH; WHITE; YOUNG, 2010), problematic usage (BIANCHI; PHILLIPS, 2005), compulsive usage (JAMES; DRENNAN, 2005), heavy usage (JENARO; FLORES; GOMEZ-VELA; GONZALEZGIL; CABALLO, 2007), intensive usage (SANCHEZ-MARTINEZ; OTERO, 2009), maladaptive usage (BERANUY; OBERST; CARBONELL; CHARMARRO, 2009), mobile dependency (BILLIEUX; VAN DER LINDEN; D'ACREMONT; CESCHI; ZERMATTEN, 2007) and addictive tendencies for mobile phone use (EHRENBERG; JUCKES; WHITE; WALSH, 2008; WALSH; WHITE; YOUNG, 2007).

Smartphone addiction and mobile phone addiction are not same. Apart from mobile phone addiction tool, smartphone addiction demands some salient criteria based on its numerous distinct features (KWON, et al., 2013). Although, previous studies have mixed-up these two distinct tools and used interchangeably (HONG, et al., 2012). Addiction in smartphone deserves distinct tool for on its salient features, such as multitasking, installing applications, internet usability. People also personalize their smartphones with various apps.

In a study, Hong et al. (2012) have developed smartphone addiction scale using mobile phone related addictive items ignoring distinct features of smartphone. Although some features of mobile phone and smartphone are same, researchers are emphasizing on the separate tool for smartphone addiction.

Some papers discuss about smartphone addiction on academic arena such as nursing student (CHO; LEE, 2015; JEONG; LEE, 2015), others emphasize specific group of generation such as youths (KIM; LEE; LEE; NAM; CHUNG, 2014) ignoring the addictive behavior of university students (with exception of SAMAHA; HAWI, 2016; HAWI; SAMAHA, 2016).

Thus, it is necessary to investigate further on academic consequences of smartphone addiction among the young generation, especially university students. 
INDEPENDENT JOURNAL OF MANAGEMENT \& PRODUCTION (IJM\&P)

http://www.ijmp.jor.br

v. 8, n. 3, July - September 2017

ISSN: 2236-269X

DOI: 10.14807/ijmp.v8i3.629

On the basis of the smartphone addiction criteria, the addiction level can be identified. For example, if a user stick with the smartphone usage and fails to reduce the usage time and feels happy in interaction with virtual friends rather than family members and friends, it indicates that the user is in addiction.

There are few studies on smartphone addiction. In a study on smartphone addiction, Cho and Kim (2014) identified gender, average daily using time in a week, average daily using time in weekend, wrist pain in using smartphone, accident in using smartphone, sociality, impulsiveness, and Social Networking Sites (SNS) addiction as significant predictors. They have found $43.3 \%$ explained variance of these factors in smartphone addiction.

Jeong and Lee (2015) studied smartphone addiction on nursing students in Korea and revealed several influencing factors of smartphone addiction that includes reading quality, the number of friends, the number of groups involved, academic achievement, average daily hours of smartphone use, and personal distress. They reported $17.4 \%$ explanatory power of these variables.

Jeong and Lee (2015) like other study (e.g., KIM; KIM; JEE, 2015) in Korea used Smartphone Addiction Proneness Scale (SAPS) that is developed by the National Information Society Agency (SHIN; KIM; JUNG, 2011). The SAPS contains 15 items consisting of four sub-domains, such as impatience, withdrawal, disturbance of adaptive functions, and virtual life orientation.

Following the previous addiction research we incorporate impatience, withdrawal, positive anticipation, cyberspace-oriented friendship, daily-life disturbance factors as influencing factors to check the smartphone addiction of undergraduate students. We hypothesize that the smartphone addiction factors influence students' academic performance. Therefore, the following hypotheses may be generated:

- $\mathrm{H} 1$ : There is an impact of cyber friendship exposed by smartphone addiction on students' academic performance;

- H2: There is an impact of daily-life disturbance exposed by smartphone addiction on students' academic performance; 
- H3: There is an impact of positive anticipation exposed by smartphone addiction on students' academic performance;

- H4: There is an impact of impatience exposed by smartphone addiction on students' academic performance;

- H5: There is an impact of withdrawal exposed by smartphone addiction on students' academic performance.

In Bangladesh, the mobile phone users are increasing rapidly and a major portion of the users are smartphone users. Among the users of smartphone, most users are young adults. Smartphone is becoming more popular among young generation, especially students.

According to Bangladesh Telecommunication Regulatory Commission (BTRC), the total number of internet subscriber is 66.862 million up to September 2016, of which 62.968 million subscribers use mobile internet. About 80 percent internet users of Bangladesh are on a single social networking website, Facebook (BTRC, 2016).

With the rapid growth of smartphone users, the negative consequences of mobile phone usage are increasing. Usage of mobile phone becomes one of the death causes when the victims walk and use mobile phone on the rail tracks.

\section{METHODOLOGY}

This is an empirical study for the identification of the Smartphone addiction factors of undergraduate students of Bangladesh. Through literature review, 35 independent variables concerning smartphone addiction have been identified and a questionnaire has been developed based on it. The reliability and validity of the questionnaire has also been tested.

Academic performance has been used as dependent variable in this study that is described as class concentration, connecing social network sites during class, class grades, study work, and overall class performance of the students.

For data collection, structured questionnaire with 5-point scale ranging from 1 ("Strongly disagree") to 5 ("Strongly agree") was used. Convenience sampling method was used for data collection. After data collection, incomplete and biased or abnormally answered data were discarded thorough scrutinizing process. 
By using SPSS software the reliability of 30 items has been tested and the Alpha Coefficient was identified as 0.746 which is at the acceptable limit as per Nunnally (1967 and 1978). To analyze data both descriptive and inferential statistics were used. A multivariate analysis technique Partial Least Square (PLS) was used to identify the significant Smartphone addiction factors from the factors identified through factor analysis. The theoretical framework of smartphone addiction of students of Bangladesh is shown in Figure 1.

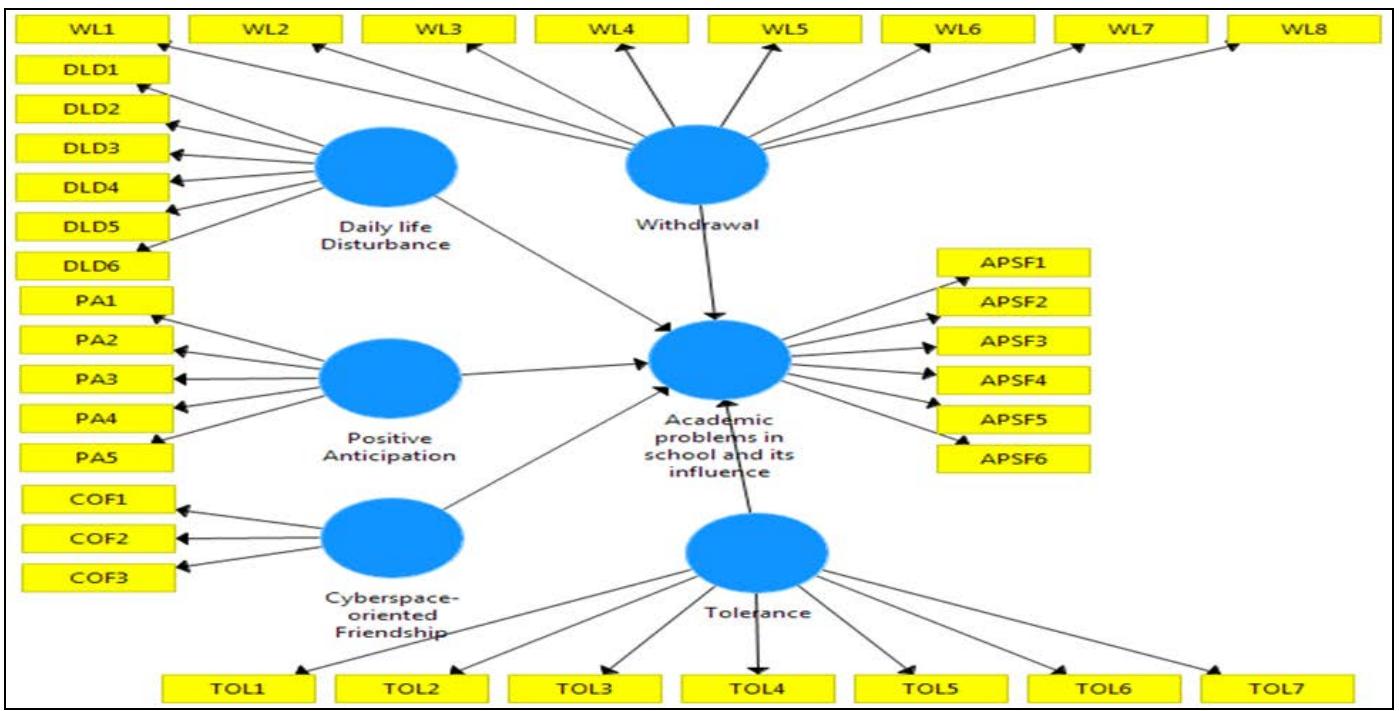

Figure 1: Conceptual Framework of Smartphone Addiction

\subsection{Sample Selection}

The sample of this study consisted of students from a private University situated in Dhaka city of Bangladesh. This study followed convenience sampling and invited students to deliberately participate in the study. We ensured whether the students have used the smartphone last twelve months continuously or not.

Because, in the pilot study we found that some students used both mobile phone and smartphone having different SIMs. Undergraduate students studying first year to fourth year participated in the study. A total of 247 students were surveyed of which $54.25 \%$ were male and $45.75 \%$ were female. The minimum and maximum age was 18 and 27 respectively. The demographic profiles of the respondents are shown in Table 1.

Table 1: Demographic Profile of the Respondent Students

\begin{tabular}{|l|l|c|c|}
\hline Demography & Gender Difference with Age & Frequency & Percentage \\
\hline Sex & Male & 134 & 54.25 \\
\cline { 2 - 4 } & Female & 113 & 45.75 \\
\hline
\end{tabular}


DOI: 10.14807/ijmp.v8i3.629

\begin{tabular}{|l|l|c|c|}
\hline \multirow{3}{*}{ Age } & Below 20 years & 48 & 19.43 \\
\cline { 2 - 4 } & $21-25$ years & 168 & 68.01 \\
\cline { 2 - 4 } & 25-30 years & 31 & 12.55 \\
\hline
\end{tabular}

\subsection{Statistical Tools}

Both descriptive and inferential statistics were used to analyze the data. Inferential statistics like Factor Analysis (FA) was used to separate the factors related to smartphone addiction factors of Bangladeshi students. Partial Least Square Method was used to identify the significant factors from the factors identified through factor analysis. SmartPLS is a software with graphical user interface for variance-based Structural Equation Modeling (SEM) using the Partial Least Squares (PLS) method. The software can be used in empirical research to analyze collected data (e.g. from surveys) and test hypothesized relationships (RINGLE, et al., 2015).

\subsection{Reliability Analysis}

To analyze the reliability (internal consistency) of the variables, this study used Cronbach's alpha coefficient and composite reliability (CR) value. Table 2 shows all Cronbach's alpha values that are above 0.60 cut off values as suggested by Nunnally and Berstein (1994). Standardized Cronbach's alpha formula is given below.

$$
\alpha=\frac{N \cdot \bar{C}}{\bar{V}+(N-1) \cdot \bar{C}}
$$

Here, $\mathrm{N}$ is equal to the number of items, C-bar is the average inter-item covariance among the items, and V-bar equals the average variance.

\subsection{Coefficient of Determination}

The reliability also finds that the coefficient of determination $R$ square $\left(R^{2}\right)$ is 0.581 for the dependent variable i.e., academic disturbance. This means that the five factors are daily-life disturbance, positive anticipation, withdrawal, cyber friendship, and impatience or tolerance moderately explain $58.10 \%$ of the variance in Smartphone addiction factors of students of Bangladesh. The reliability and validity test results are under the acceptable limits (Table 2).

Table 2: Results of Reliability Tests 
INDEPENDENT JOURNAL OF MANAGEMENT \& PRODUCTION (IJM\&P)

http://www.ijmp.jor.br

v. 8, n. 3, July - September 2017

ISSN: 2236-269X

DOI: 10.14807/ijmp.v8i3.629

\begin{tabular}{|l|l|l|l|l|}
\hline & \multicolumn{1}{|c|}{ Extracted (AVE) } & Reliability & \multicolumn{1}{|c|}{ Alpha } & Validity \\
\hline 1. Cyber Friendship & 0.603 & 0.751 & 0.647 & 0.776 \\
\hline 2. Daily-life Disturbance & 0.508 & 0.754 & 0.639 & 0.713 \\
\hline 3. Positive Anticipation & 0.592 & 0.743 & 0.612 & 0.769 \\
\hline 4. Impatience / Tolerance & 0.613 & 0.755 & 0.692 & 0.783 \\
\hline 5. Withdrawal & 0.520 & 0.763 & 0.742 & 0.721 \\
\hline
\end{tabular}

Generally, a Global Fit measure (GOF) was conducted for path modeling. It is defined as the geometric mean of average communality and average $\mathrm{R}^{2}$ (especially endogenous variables) (Chin, 2010) (see the formula). In this study, GOF value was $0.46\left(R^{2}=0.581\right.$, average AVE $=0.5674$ for overall addiction factors $)$. So, the value of GOF exceeded the largest cut-off value (0.46) and it was indicated that the proposed model of this study had better explaining power based on the recommended value of GOF small $=0.1$, GOF medium $=0.25$, and GOF large $=0.36$ (AKTER et al., 2011).

\section{$\mathrm{GOF}=\sqrt{A V E \times R^{2}}$}

\subsection{Validity Analysis: Convergent Validity}

Whenever many items are utilized to measure a single construct, the item (indicator) convergent validity should be one of the main concerns to the researcher. In this article the model was tested for convergent validity to measure the extent to which different items are in agreement (MACKINNON, 2008).

When all the factor loadings for the items used in the same construct are statistically significant convergent validity is tested (GERBING; ANDERSON,1988). In addition, it could also be accessed through factor loadings, composite reliability and the average variance extracted (HAIR, et al., 1998).

The findings of the model (Table 2) show that the factor loadings for all items exceeded the recommended value of 0.50 (Hair et al., 1998). Composite reliability (CR) values in this study are ranged from 0.743 to 0.763 which exceeded the acceptable value of 0.70 (HAIR, et al., 1998). Thus, the model confirmed adequate convergent validity.

\subsection{Validity Analysis: Discriminant Validity}

The discriminant validity indicates the degree to which the variables of a given model vary from variables of other variables in the same model (MACKINNON, 2008). To conduct Partial Least Squares (PLS) analysis the important thing for 
INDEPENDENT JOURNAL OF MANAGEMENT \& PRODUCTION (IJM\&P)

http://www.ijmp.jor.br

V. 8, n. 3, July - September 2017

ISSN: 2236-269X

DOI: 10.14807/ijmp.v8i3.629

discriminant validity is its construct that share more difference with its variables than that of other constructs in a specific model (HULLAND, 1999).

In this study, the discriminant validity of the instrument has been tested. It has been evaluated by examining the correlations between the measures of potentially overlapping constructs. Factor loadings are stronger on their own constructs in the model and the square root of the average variance extracted for each construct is greater than the levels of correlations involving the construct (FORNELL; LARCKER, 1981).

The square root of the average variance extracted for each construct is greater than the items on off-diagonal in their corresponding row and column, thus, indicating the adequate discriminant validity (Table 2). The inter-construct correlations demonstrate that every construct shares greater variance values with its own measures than other measures. Thus, the model confirmed adequate discriminant validity.

\subsection{Average Variance Extracted}

All values of the Average Variance Extracted (AVE) that deals the variance captured by the indicators relative to measurement error were greater than 0.50 that indicate acceptability of the constructs (FORNELL; LARCKER, 1981; HENSELER; RINGLE; SINKOVICS, 2009). Table 2 shows that these indicators satisfied the convergent validity of the constructs.

\section{RESULTS \& DISCUSSIONS}

\subsection{Results of Factor Analysis}

Exploratory factor analysis was used in analyzing the data which is a widely utilized and broadly applied statistical techniques in social science. The factor analysis technique has been applied to identify the factors that affect the smartphone addiction of the business students in Bangladesh.

A total of 35 variables were identified for smartphone addiction of students through literature review. The variables were categorized into five factors which were found from rotated factor matrix analysis (Table 3). The factors are: (i) Daily-life Disturbance, (ii) Positive Anticipation, (iii) Withdrawal, (iv) Cyber Friendship, and (v) Impatience or Tolerance. 
DOI: 10.14807/ijmp.v8i3.629

\subsubsection{Daily-life Disturbance}

This factor includes variables like: "Missing planned works hard time concentrating in class, Felling tired and lacking adequate sleep", "Decreasing relationship with family", "Feeling pain in the wrists", etc. which are the major components of daily-life disturbances.

It is the most important factor concerned with smartphone addiction of the business students in Bangladesh as it contains highest eigenvalue. This indicates that the use of smartphone is not only the concern of the academic performance but also disturbes the family relationhsips, planned work, on-time show up in class and physical soundness.

\subsubsection{Positive Anticipation}

The second important factor of smartphone addiction is positive anticipation that includes the variables like "Feeling pleasant or excited", "Feeling confident", "Being able to get rid of stress, life would be empty without my Smartphone", etc. These are found to be the major components of positive anticipation.

\subsubsection{Withdrawal}

The third important smartphone addiction factor is withdrawal that includes variables like "Feeling impatient and fretful", "Bringing my smartphone to the toilet", "Feel anxious about not being able to receive important calls", "Can't stop using my Smartphone", etc. These are the major components of withdrawal.

\subsubsection{Cyber Friendship}

This factor includes variables like "relationships with my smartphone buddies are more intimate", "Constantly checking my Smartphone", "Checking SNS sites", etc. which are the major components of cyber friendship.

\subsubsection{Increased Impatience or Tolerance}

This factor includes variables like "Always thinking that I should shorten my Smartphone use time", "Feel the urge to use my smartphone", "I spend my break time, thinking -just give me some more minutes" etc. which are the major components of impatience. This indicates that the use of smartphone increases impatience among the students for doing their regular activities as it consumes most of their valuable times. 
INDEPENDENT JOURNAL OF MANAGEMENT \& PRODUCTION (IJM\&P)

http://www.ijmp.jor.br

v. 8, n. 3, July - September 2017

ISSN: 2236-269X

DOI: 10.14807/ijmp.v8i3.629

Table 3: Smartphone Addiction Factors of the Business Students

\begin{tabular}{|c|c|c|c|c|c|c|c|}
\hline Factors & Items & $\begin{array}{c}\text { Outer } \\
\text { Loadings }\end{array}$ & t-value & $\mathrm{CR}$ & AVE & Alpha & VIF \\
\hline \multirow{2}{*}{ Cyber Friendship } & $\begin{array}{l}\text { Relationships with } \\
\text { Smartphone buddies are } \\
\text { more intimate }\end{array}$ & 0.707 & 5.603 & \multirow[t]{2}{*}{0.647} & \multirow[t]{2}{*}{0.751} & \multirow[t]{2}{*}{0.603} & 1.046 \\
\hline & $\begin{array}{l}\text { Checking SNS sites right } \\
\text { after waking up }\end{array}$ & 0.840 & 8.343 & & & & 1.046 \\
\hline \multirow{3}{*}{ Daily-life Disturbance } & $\begin{array}{l}\text { Relationship with family } \\
\text { members is decreasing }\end{array}$ & 0.606 & 8.434 & \multirow{3}{*}{0.639} & \multirow{3}{*}{0.754} & \multirow{3}{*}{0.508} & 1.202 \\
\hline & $\begin{array}{l}\text { Never give up using } \\
\text { Smartphone even if it hurts } \\
\text { everyday life }\end{array}$ & 0.785 & 32.323 & & & & 1.211 \\
\hline & $\begin{array}{l}\text { Feeling pain in the wrists } \\
\text { or at the back of the neck }\end{array}$ & 0.736 & 26.085 & & & & 1.080 \\
\hline \multirow{2}{*}{ Positive Anticipation } & $\begin{array}{l}\text { Feeling pleasant or excited } \\
\text { while using a Smartphone }\end{array}$ & 0.730 & 6.666 & \multirow{2}{*}{0.612} & \multirow{2}{*}{0.743} & \multirow{2}{*}{0.592} & 1.035 \\
\hline & $\begin{array}{l}\text { Feeling confident while } \\
\text { using a Smartphone }\end{array}$ & 0.806 & 9.133 & & & & 1.035 \\
\hline \multirow[b]{2}{*}{ Impatience/Tolerance } & $\begin{array}{l}\text { Used Smartphone for } \\
\text { longer than intended }\end{array}$ & 0.652 & 6.755 & \multirow[b]{2}{*}{0.692} & \multirow[b]{2}{*}{0.755} & \multirow[b]{2}{*}{0.613} & 1.063 \\
\hline & $\begin{array}{l}\text { Thinking just give me some } \\
\text { more minutes to use } \\
\text { smartphone }\end{array}$ & 0.894 & 19.717 & & & & 1.063 \\
\hline \multirow{3}{*}{ Withdrawal } & $\begin{array}{l}\text { Feeling impatient and } \\
\text { fretful when not holding } \\
\text { Smartphone }\end{array}$ & 0.779 & 12.202 & \multirow[t]{3}{*}{0.742} & \multirow[t]{3}{*}{0.763} & \multirow[t]{3}{*}{0.520} & 1.152 \\
\hline & $\begin{array}{l}\text { Bringing Smartphone to } \\
\text { the toilet }\end{array}$ & 0.755 & 14.348 & & & & 1.183 \\
\hline & $\begin{array}{l}\text { Lacking adequate sleep } \\
\text { due to smartphone use }\end{array}$ & 0.619 & 6.454 & & & & 1.113 \\
\hline
\end{tabular}

\section{2. $\quad$ Results of Multivariate Analysis - Partial Least Squares (PLS)}

A multivariate analysis technique like Structural Equation Modeling (SEM), by using 'SmartPLS', has been used to identify the significant smartphone addiction factors from the factors identified through factor analysis. Path diagram of smartphone addiction factors of business students of Bangladesh suggested that the disturbance of daily-life activities $(\beta=1.123)$ has the strongest effect on student's academic performance.

The hypothesized path relationships between daily-life disturbance, impatience and academic disturbance of the students are highly significant at $1 \%$ level of significance. This is due to direct link with the academic affairs of the students. On the other hand, the cyber friendships, positive anticipation, and withdrawal factors are not significantly related to academic disturbance of the students (Figure 2). The reasons might be attributed by the adaptation with the new technology and the satisfaction of the students. 
INDEPENDENT JOURNAL OF MANAGEMENT \& PRODUCTION (IJM\&P)

http://www.ijmp.jor.br

v. 8, n. 3, July - September 2017

ISSN: 2236-269X

DOI: 10.14807/ijmp.v8i3.629

Figure 2 also shows relationships of the variables constituted the smartphone addiction factors and their relative importance, relationships with the factors, and the overall students' academic performance of the students of Bangladesh.

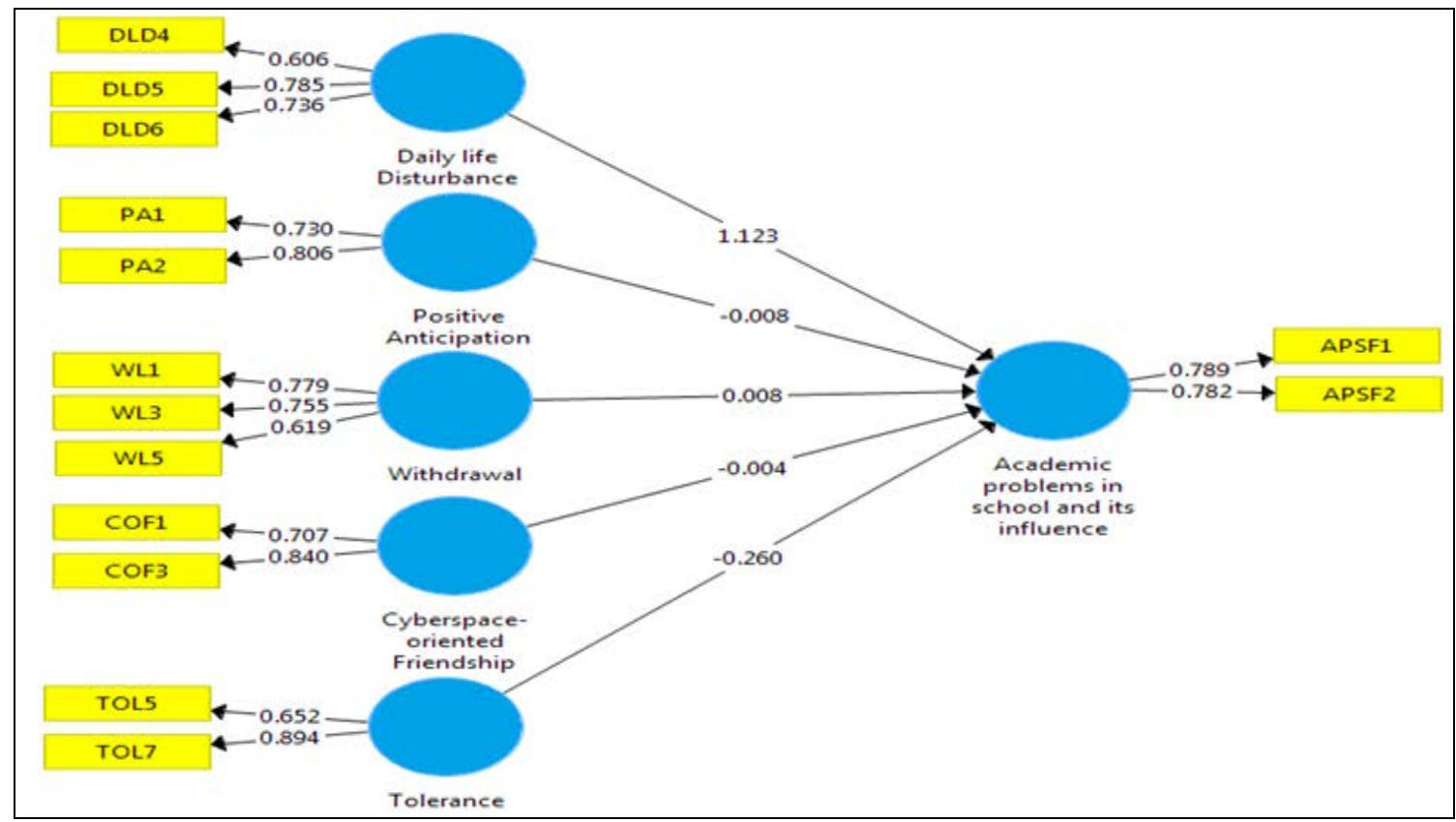

Figure 2. Relationships of Smartphone Addiction Factors with the Academic

Performance of the Students

The path coefficients of the factors concerned with smartphone addiction factors of students show that daily-life disturbance is the most important factor of academic performance due to smartphone addiction $(\beta=1.123)$ (Table 4).

Table 4: Path Coefficient of the Smartphone Addiction Factors

\begin{tabular}{|c|c|c|c|c|c|c|c|}
\hline Path Coefficients & $\begin{array}{l}\text { Original } \\
\text { Sample } \\
(\mathrm{O})\end{array}$ & $\begin{array}{l}\text { Sample } \\
\text { Mean } \\
\text { (M) }\end{array}$ & $\begin{array}{l}\text { Standard } \\
\text { Deviation } \\
\text { (STDEV) }\end{array}$ & $\begin{array}{l}\text { T Statistics } \\
(|\mathrm{O} / \mathrm{STDEV}|)\end{array}$ & $\begin{array}{l}\mathrm{P} \\
\text { Values }\end{array}$ & $\begin{array}{l}\text { Supported/ } \\
\text { Not } \\
\text { Supported }\end{array}$ & VIF \\
\hline $\begin{array}{l}\text { Cyberspace-oriented } \\
\text { Friendship ->Academic } \\
\text { performance in school and } \\
\text { its influence }\end{array}$ & -0.004 & -0.004 & 0.009 & 0.503 & 0.615 & $\begin{array}{l}\text { Not } \\
\text { Supported }\end{array}$ & 1.185 \\
\hline $\begin{array}{l}\text { Daily life Disturbance - } \\
>\text { Academic performance in } \\
\text { school and its influence }\end{array}$ & 1.123 & 1.124 & 0.034 & 33.200 & 0.000 & Supported & 1.752 \\
\hline $\begin{array}{l}\text { Positive Anticipation - } \\
\text { >Academic performance in } \\
\text { school and its influence }\end{array}$ & -0.008 & -0.007 & 0.009 & 0.883 & 0.378 & $\begin{array}{l}\text { Not } \\
\text { Supported }\end{array}$ & 1.165 \\
\hline $\begin{array}{l}\text { Impatience ->Academic } \\
\text { performance in school and } \\
\text { its influence }\end{array}$ & -0.260 & -0.257 & 0.043 & 6.115 & 0.000 & Supported & 1.588 \\
\hline $\begin{array}{l}\text { Withdrawal ->Academic } \\
\text { performance in school and } \\
\text { its influence }\end{array}$ & 0.008 & 0.006 & 0.010 & 0.773 & 0.440 & $\begin{array}{l}\text { Not } \\
\text { Supported }\end{array}$ & 1.431 \\
\hline R Square & \multicolumn{7}{|c|}{0.581} \\
\hline
\end{tabular}


In Table 4, all the Variance Inflation Factor (VIF) values are less than 3 that range from 1.165 to 1.752 , which indicates there is no Multi Co-linearity problem.

The hypothesis testing was carried out by examining the path coefficients (beta) between latent constructs and their significance. To test the significance of the path coefficients the bootstrapping technique was utilized with a re-sampling of 500 (e.g., BRADLEY et al., 2012).

The $R^{2}$ value of endogenous latent construct illustrates the predictive relevance of the model. The $\mathrm{R}^{2}$ value is 0.581 . The findings show that the hypotheses $\mathrm{H}_{2}$, and $\mathrm{H}_{4}$ were rejected on the basis t-values which is higher than 3.3 at the $0.1 \%$ level of significance but $\mathrm{H}_{1}, \mathrm{H}_{3}$ and $\mathrm{H}_{5}$ were not rejected the null hypothesis on the basis of t-values which is not more than 1.96 at the $5 \%$ level of significance. This is also depicted in Figure 2. The outcome of each hypothesis is mentioned into the conclusions. Table 5 presents the results of the hypotheses testing.

Table 5: Results of the Relationships

\begin{tabular}{|l|l|r|}
\hline $\mathrm{H}_{1}$ & $\begin{array}{l}\text { There is an impact of cyber friendship exposed by smartphone } \\
\text { addiction on students' academic performance }\end{array}$ & NotSupported \\
\hline $\mathrm{H}_{2}$ & $\begin{array}{l}\text { There is an impact of daily-life disturbance exposed by smartphone } \\
\text { addiction on students' academic performance }\end{array}$ & Supported \\
\hline $\mathrm{H}_{3}$ & $\begin{array}{l}\text { There is an impact of positive anticipation exposed by smartphone } \\
\text { addiction on students' academic performance }\end{array}$ & Supported \\
\hline $\mathrm{H}_{4}$ & $\begin{array}{l}\text { There is an impact of impatience exposed by smartphone addiction on } \\
\text { students' academic performance. }\end{array}$ & Not Supported \\
\hline $\mathrm{H}_{5}$ & $\begin{array}{l}\text { There is an impact of withdrawal exposed by smartphone addiction on } \\
\text { students' academic performance }\end{array}$ & \\
\hline
\end{tabular}

\section{CONCLUSIONS AND RECOMMENDATIONS}

Five factors concerning smartphone addiction of the business students of private university in Bangladesh were identified in this study. The factors are positive anticipation, increased impatience or tolerance, withdrawal, daily-life disturbance, and cyber friendship. Although, all the factors identified in this study are not equally significant but as a whole those are the significant factors that determine the addiction of smartphone use of business students and has impact on their academic performance.

As longer time is spent on the smartphone by the students, reading quantity and participation in group activities concerning academic assignments are reduced (JEONG; LEE, 2015; SAMAHA; HAWI, 2016). The relationships between the uses of 
INDEPENDENT JOURNAL OF MANAGEMENT \& PRODUCTION (IJM\&P)

http://www.ijmp.jor.br

v. 8, n. 3, July - September 2017

ISSN: 2236-269X

DOI: 10.14807/ijmp.v8i3.629

smartphone and classroom listening is significant for good academic performance (JUMOKE; OLORUNTOBA; BLESSING, 2015).

This study identified that the regular academic performance of the students are hampered by the extensive use of smartphone that contradicts the findings of the research conducted by Ezemenaka (2013). Students know that the excessive use of smartphone is harmful to their body and mind. Sometimes, the use of smartphone is uncontrollable to the students (JUMOKE; OLORUNTOBA; BLESSING, 2015).

They, sometimes, try to shorten their smartphone usage but are unable to do it due to addiction. This study found that students use their smartphone longer than they plan. Sometimes, they want to engage in smartphone usage time beyond the regular usage. Students use smartphone in the break-time of classes when they are supposed to relax.

The addictive behavior of smartphone usage also hampers students' concentration to their studies (HISCOCK, 2004; SELWYN, 2003; SAMAHA; HAWI, 2016; HAWI; SAMAHA, 2016). Students feel anxious when they do not have smartphone with them. This study found that they bring smartphone in the toilet even if they are hurry to get there. Some students even use their smartphone until the late night. These can cause tension and poor academic performance of the students.

It is commonly known that smartphones are used in the daily-life of the people. But addiction to smartphone causes disturbances of the daily-life activities. This study found that due to excessive use of smartphone, the relationships of the students with the family members are hampered.

They cannot give enough time to their families due to extensive use of smartphone. When student gossip with family members, they simultaneously communicate with their virtual friends even if they are in the middle of the discussion. This causes pain in the wrists or at the back or neck of the students.

The major findings of this study are concerned with the disturbance of the daily life activities and the increased impatience of the students due to intense use of smartphone. Smartphone addiction not only the cause of poor academic performance but also disturbs daily-life activities of the students. It creates impatience among the students for doing their daily-life activities. 
INDEPENDENT JOURNAL OF MANAGEMENT \& PRODUCTION (IJM\&P)

http://www.ijmp.jor.br

v. 8, n. 3, July - September 2017

ISSN: 2236-269X

DOI: 10.14807/ijmp.v8i3.629

Based on the findings, it is recommended that the students should reduce the use of smartphone and addiction to it and priorities their day-to-day tasks (HISCOCK, 2004; SELWYN, 2003). However, this study did not include the factors that are not related to the use of smartphone that also create addiction such as, availability of the smart phones and its services, low cost of the internet connection, extensive use of the phones by all the classes of the people even street beggar, and, of course, demonstration effect.

This study only concentrates on the business students of a private university of Bangladesh. The results might be different in case of other students like science, engineering, arts, and social sciences of the other Universities of Bangladesh.

\section{REFERENCES}

AKERS, R. L. (1991). Addiction: The troublesome concept. Journal of Drug Issues, v. 21, n. 4, p. 777-793.

AKTER, S.; D'AMBRA, J.; RAY, P. (2011). Trustworthiness in mHealth information services: an assessment of a hierarchical model with mediating and moderating effects using partial least squares (PLS). Journal of the American Society for Information Science and Technology, v. 62, n. 1, p. 100-116.

BANGLADESH TELECOMMUNICATION REGULATORY COMMISSION (BTRC) (visited 9 December, 2016) http://www.btrc.gov.bd/content/internet-subscribersbangladesh-september-2016

BIANCHI, A.; PHILLIPS, J. G. (2005). Psychological predictors of problem mobile phone use. CyberPsychology \& Behavior, v. 8, n. 1, p. 39-51.

BILLIEUX, J.; VAN DER LINDEN, M.; D'ACREMONT, M.; CESCHI, G.; ZERMATTEN, A. (2007). Does impulsivity relate to perceived dependence on and actual use of the mobile phone?. Applied Cognitive Psychology, v. 21, n. 4, p. 527-537.

BERANUY, M.; OBERST, U.; CARBONELL, X.; CHAMARRO, A. (2009).

Problematic Internet and mobile phone use and clinical symptoms in college students: The role of emotional intelligence. Computers in Human Behavior, v. 25, n. 5, p. 1182-1187.

BRENNER, V. (1997). Psychology of computer use: XLVII. Parameters of Internet use, abuse and addiction: the first 90 days of the Internet Usage Survey.

Psychological Reports, v. 80, n. 3, p. 879-882.

BRATTER, T. E.; FORREST, G. G. (1985). Alcoholism and Substance Abuse: Strategies for Clinical Intervention. Simon and Schuster.

BRADLEY, S. E.; CROFT, T. N.; FISHEL, J. D.; WESTOFF, C. F. (2012). Revising unmet need for family planning. DHS Analytical Studies No. 25. Calverton, Maryland, USA: ICF International.

CARNES, P. (1983). The sexual addiction. CompCare Publications. 
CHO, G. Y.; KIM, Y. H. (2014). Factors affecting smartphone addiction among university students. Journal of the Korea Academia-Industrial Cooperation Society, v. 15, n. 3, p. 1632-1640.

$\mathrm{CHO}, \mathrm{S}$.; LEE, E. (2015). Development of a brief instrument to measure smartphone addiction among nursing students. CIN: Computers, Informatics, Nursing, v. 33, n. 5, p. 216-224.

CHIN, W. W. (2010). How to write up and report PLS analyses. In Handbook of Partial Least Squares (p. 655-690). Springer Berlin Heidelberg.

CHIU, S. I. (2014). The relationship between life stress and smartphone addiction on Taiwanese university student: A mediation model of learning self-Efficacy and social self-Efficacy. Computers in Human Behavior, n. 34, p. 49-57.

EHRENBERG, A.; JUCKES, S.; WHITE, K. M.; WALSH, S. P. (2008). Personality and self-esteem as predictors of young people's technology use. Cyberpsychology \& Behavior, v. 11, n. 6, p. 739-741.

EZEMENAKA, E. (2013). The usage and impact of Internet enabled phones on academic concentration among students of tertiary institutions: A study at the University of Ibadan, Nigeria. International Journal of Education and Development using Information and Communication Technology, v. 9, n. 3, p. 162-173.

ERICSSON MOBILITY REPORT (2015). South East Asia and Oceania, retrieved in 15 December, 2016, https://www.ericsson.com/assets/local/mobilityreport/documents/2015/emr-nov-2015-regional-report-south-east-asia-andoceania.pdf

FORNELL, C.; LARCKER, D. F. (1981). Evaluating structural equation models with unobservable variables and measurement error. Journal of Marketing Research, $v$. 18, n. 1, p. 39-50.

GERBING, D. W.; ANDERSON, J. C. (1988). An updated paradigm for scale development incorporating unidimensionality and its assessment. Journal of marketing research, p. 186-192.

GLANZE, W. D.; ANDERSON, K.; ANDERSON, L. E. (1998). Mosby's Medical, Nursing, and Allied Health Dictionary. 5th ed. St Louis: Mosby.

GRIFFITHS, M. D. (1990). The cognitive psychology of gambling. Journal of Gambling Studies, v. 6, n. 1, p. 31-42.

GRIFLLTHS, M. D. (1998). Internet addiction: does it really exist?. Gackenbach J. Psychology and the Intemet: Intrapersonal, Interpersonal, and Transpersonal Implications. New York: Academic Press, p. 61-75.

GRIFFITHS, M. D.; HUNT, N. (1995). Computer game playing in adolescence: Prevalence and demographic indicators. Journal of Community \& Applied Social Psychology, v. 5, n. 3, p. 189-193.

GOLDBERG, I. (1995). Internet addictive disorder (IAD) diagnostic criteria. $<$ http://www.psycom.net/iadcriteria.html>

HAIR, J. F.; ANDERSON, R. E.; TATHAM, R. L.; BLACK, W. C. (1998). Multivariate Data Analysis with Readings, 5th Edition. Macmillan, New York. 
HAWI, N. S.; SAMAHA, M. (2016). To excel or not to excel: Strong evidence on the adverse effect of smartphone addiction on academic performance. Computers \& Education, n. 98, p. 81-89.

HENSELER, J.; RINGLE, C. M.; SINKOVICS, R. R. (2009). The use of partial least squares path modeling in international marketing. New Challenges to International Marketing Advances in International Marketing, n. 20, p. 227-319.

HISCOCK, D. (2004). Cell phones in class: This, too, shall pass. Community College Week, v. 16, n. 16, p. 4-5.

HONG, F. Y.; CHIU, S. I.; HUANG, D. H. (2012). A model of the relationship between psychological characteristics, mobile phone addiction and use of mobile phones by Taiwanese university female students. Computers in Human Behavior, v. 28, n. 6 , p. $2152-2159$.

HULLAND, J. (1999). Use of Partial Least Squares (PLS) in strategic management research: a view of four recent studies. Strategic Management Journal, n. 20, p. 195-204.

JAMES, D.; DRENNAN, J. (2005). Exploring addictive consumption of mobile phone technology. In Australian and New Zealand Marketing Academy conference, Perth, Australia.

JEONG, H.; LEE, Y. (2015). Smartphone addiction and empathy among nursing students. Advanced Science and Technology Letters, n. 88, p. 224-228.

JENARO, C.; FLORES, N.; GÓMEZ-VELA, M.; GONZÁLEZ-GIL, F.; CABALLO, C. (2007). Problematic internet and cell-phone use: Psychological, behavioral, and health correlates. Addiction Research \& Theory, v. 15, n. 3, p. 309-320.

JUMOKE, S.; OLORUNTOBA, S. A.; BLESSING, O. (2015). Analysis of Mobile Phone Impact on Student Academic Performance in Tertiary Institution.

International Journal of Emerging Technology and Advanced Engineering, v. 5, n. 1.

KANDELL, J. J. (1998). Internet addiction on campus: The vulnerability of college students. CyberPsychology \& Behavior, v. 1, n. 1, p. 11-17.

KIM, S. E.; KIM, J. W.; JEE, Y. S. (2015). Relationship between smartphone addiction and physical activity in Chinese international students in Korea. Journal of Behavioral Addictions, v. 4, n. 3, p. 200-205.

KIM, D.; LEE, Y.; LEE, J.; NAM, J. K.; CHUNG, Y. (2014). Development of Korean smartphone addiction proneness scale for youth. PLoS One, v. 9, n. 5, p. e97920.

KO, C. H.; YEN, J. Y.; CHEN, C. C.; CHEN, S. H.; WU, K.; YEN, C. F. (2006).

Tridimensional personality of adolescents with internet addiction and substance use experience. The Canadian Journal of Psychiatry, v. 51, n. 14, p. 887-894.

KOO, H. Y. (2009). Development of a cell phone addiction scale for Korean adolescents. Journal of Korean Academy of Nursing, v. 39, n. 6.

KUSS, D. J.; GRIFFITHS, M. D. (2011). Online social networking and addiction-a review of the psychological literature. International Journal of Environmental

Research and Public Health, v. 8, n. 9, p. 3528-3552. 
KWON, M.; LEE, J. Y.; WON, W. Y.; PARK, J. W.; MIN, J. A.; HAHN, C.; KIM, D. J. (2013). Development and validation of a smartphone addiction scale (SAS). PloS one, v. 8, n. 2, p. e56936.

MACKINNON, D. P. (2008). Introduction to statistical mediation analysis. Mahwah, NJ: Erlbaum.

NUNNALLY, J. C. (1967). Psychometric Theory, 1st ed., New York: McGraw-Hill.

NUNNALLY, J. C. (1978). Introduction to Psychological Measurement, New York: McGraw-Hill.

NUNNALLY, J. C.; BERNSTEIN, I. H. (1994). Psychometric Theory, (3 ${ }^{\text {rd }}$ ed.), New York: McGraw-Hill.

ÖZCAN, Y. Z.; KOÇAK, A. (2003). Research note: A need or a status symbol? Use of cellular telephones in Turkey. European Journal of Communication, v. 18, n. 2, p. 241-254.

PEELE, S. (1985). The meaning of addiction: Compulsive experience and its interpretation. Lexington Books/DC Heath and Com.

RACHLIN, H. (1990). Why do people gamble and keep gambling despite heavy losses? Psychological Science, v. 1, n. 5, p. 294-297.

RINGLE, C. M.; WENDE, S.; BECKER, J. M. (2015). SmartPLS 3. Boenningstedt: SmartPLS.

SAMAHA, M.; HAWI, N. S. (2016). Relationships among smartphone addiction, stress, academic performance, and satisfaction with life. Computers in Human Behavior, n. 57, p. 321-325.

SÁNCHEZ-MARTÍNEZ, M.; OTERO, A. (2009). Factors associated with cell phone use in adolescents in the community of Madrid (Spain). CyberPsychology \& Behavior, v. 12, n. 2, p. 131-137.

SELWYN, N. (2003). Schooling the mobile generation: The future for schools in the mobile-networked society. British Journal of Sociology of Education, v. 24, n. 2, p. 131-144.

SHIN, K. W.; KIM, D. I.; JUNG, Y. J. (2011) Development of Korean smart phone addiction proneness scale for youth and adults. Seoul: Korean National Information Society Agency.

WALKER, M. B. (1989). Some problems with the concept of "gambling addiction": Should theories of addiction be generalized to include excessive gambling? Journal of Gambling Behavior, v. 5, n. 3, p. 179-200.

WALSH, S.; WHITE, K. (2006). Ring, ring, why did I make that call?. Youth Studies Australia, v. 25, n. 3.

WALSH, S. P.; WHITE, K. M. (2007). Me, My Mobile, and I: The Role of Self-and Prototypical Identity Influences in the Prediction of Mobile Phone Behavior. Journal of Applied Social Psychology, v. 37, n. 10, p. 2405-2434.

WALSH, S. P.; WHITE, K. M.; YOUNG, R. M.; WALSH, M. S. (2007). Young and connected: Psychological influences of mobile phone use amongst Australian youth. In Eds.; University of Sydney. 
WALSH, S. P.; WHITE, K. M.; MCD YOUNG, R. (2010). Needing to connect: The effect of self and others on young people's involvement with their mobile phones. Australian Journal of Psychology, v. 62, n. 4, p. 194-203.

YOUNG, K. S. (1998). Internet addiction: The emergence of a new clinical disorder. Cyberpsychology \& Behavior, v. 1, n. 3, p. 237-244. 